\title{
Influence of agents that affect intracellular calcium regulation on progesterone secretion in small and large luteal cells of the sheep
}

\author{
P. B. Hoyer and S. L. Marion \\ Department of Physiology, Arizona Health Sciences Center, University of Arizona, Tucson, \\ AZ 85724, USA
}

\begin{abstract}
Summary. Enriched fractions of small and large luteal cells were incubated for $2 \mathrm{~h}$ with 1 or $10 \mu \mathrm{M}$ calcium ionophore, A23187: unstimulated secretion of progesterone and viability in small cells were not affected but these measures were decreased $(P<0.01)$ for unstimulated large cells and were significantly correlated $(P<0.05)$. This effect in large cells was independent of extracellular calcium. Therefore, incubations of the two cell types were made in the presence of increasing concentrations of a protein kinase $\mathrm{C}$ activator, phorbol 12-myristate 13-acetate (TPA). Secretion of progesterone and viability were not augmented in unstimulated small cells, but TPA prevented $(P<0.05)$ the full stimulation of secretion of progesterone by $\mathrm{LH}$. Secretion of progesterone in unstimulated large cells was inhibited $(P<0.01)$ by TPA $(100 \mathrm{nM}$ and $10 \mu \mathrm{M})$, although viability was unaffected. The non-tumour promoting phorbol ester, $4 \alpha$-phorbol didecanoate, had no effect on large cells. Extracellular calcium was not required for the observed effect of TPA. Sphingosine, an agent inhibitory to protein kinase $\mathrm{C}$ activity, inhibitied $(P<0.01)$ secretion of progesterone in small and large cells, and also reduced $(P<0.01)$ cell viability. These values were significantly correlated $(P<0.05)$ in both cell types. The above observations suggest that protein kinase $\mathrm{C}$ may invoke negative regulation on progesterone production in unstimulated large and hormone-stimulated small luteal cells of sheep. Since sphingosine significantly reduced viability in small and large cells and ionophore selectively inhibited viability in large cells, the ability of these agents to influence calcium-mediated intracellular regulation of steroidogenesis is still uncertain.
\end{abstract}

Keywords: corpus luteum; small and large cells; C kinase; ewe

\section{Introduction}

Luteinizing hormone $(\mathrm{LH})$ stimulates secretion of progesterone, intracellular accumulation of adenosine $3^{\prime}, 5^{\prime}$-monophosphate (cAMP) and adenylate cyclase activity in luteal tissue (Marsh et al., 1966; Marsh, 1970). Luteolysis can be induced in many species, including the ewe (McCracken et al., 1970), by prostaglandin (PG) F-2 $\alpha$. The mechanism of action for this event is not as well understood.

Recent research (reviewed by Berridge, 1984) has suggested that calcium-dependent second messengers (inositol trisphosphate and diacylglycerol) produced in many tissues by hormonallyinduced hydrolysis of polyphosphatidyl inositol may mediate hormone action via cAMP. independent protein kinases. Investigators have suggested that, along with $\mathrm{A}$ kinase, $\mathrm{C}$ kinase (calcium, phospholipid-dependent; Clark et al., 1983; Davis \& Clark, 1983; Wheeler \& Veldhuis, 1987) and calmodulin-dependent protein kinase(s) (Maizels \& Jungmann, 1983; Rao et al., 1987) 
may be involved in regulating steroidogenesis in ovarian tissues. Increases in inositol trisphosphate and intracellular calcium have been observed to be stimulated by LH (Davis et al., 1987a) and PGF-2 $\alpha$ (Davis et al., 1987b) in bovine luteal cells.

The corpus luteum of many species, including the ewe, contains two morphologically and functionally distinct types of steroidogenic cells, designated small and large (O'Shea et al., 1979; Rodgers \& O'Shea, 1982; Fitz et al., 1982). The small luteal cells (12-22 $\mu \mathrm{m}$ diameter) of sheep contain a large number of receptors for LH (Fitz et al., 1984) which appear to be functionally linked to steroidogenesis through a cAMP-dependent pathway (Hoyer et al., 1984; Hoyer \& Niswender, 1985, 1986). The large luteal cells $(>22 \mu \mathrm{m}$ diameter) of sheep contain a significant number of receptors for PGF-2 $\alpha$ (Fitz et al., 1982; BaLapure et al., 1988) and secretion of progesterone was inhibited after $6 \mathrm{~h}$ in large cells incubated with PGF-2 $\alpha$ (Fitz et al., 1984). Large cells do not respond to $\mathrm{LH}$ or hormone-independent activation of the cAMP pathway (Hoyer \& Niswender, 1985) with increased steroid production; however, unstimulated secretion of progesterone is 5-10 times greater in large than in small cells, on a per cell basis (Fitz et al., 1982; Rodgers et al., 1983; Hoyer et al., 1984).

Secretion of progesterone was stimulated by low concentrations of phorbol esters (activators of C kinase) in bovine luteal cells (Brunswig et al., 1986; Hansel \& Dowd, 1986) and specifically in small luteal cells obtained from the bovine corpus luteum (Alila et al., 1988). Conversely, phorbol esters have been reported to have inhibitory effects on LH-stimulated progesterone secretion and cAMP accumulation in rat luteal cells (Baum \& Rosberg, 1987) and on LH-stimulated progesterone secretion in cow (Benhaim et al., 1987) and sheep (Wiltbank et al., 1988) small luteal cells. Furthermore, secretion of progesterone by unstimulated large luteal cells of sheep was inhibited by incubation with TPA (Hoyer et al., 1988; Wiltbank et al., 1988).

In the present study we have further evaluated a possible role of calcium as an intracellular mediator of steroidogenesis in small and large luteal cells of sheep. We have observed the effect of calcium ionophore (A23187) and phorbol ester (phorbol 12-myristate, 13-acetate; TPA) on secretion of progesterone in these cells.

The effect of these agents on cell viabilities was also investigated along with the dependence of these events on extracellular calcium.

\section{Materials and Methods}

Tissue collection. Corpora lutea (CL) were surgically collected from superovulated western range ewes (Hild-Petito et al., 1987) and placed in sterile Medium 199 (Gibco Laboratories, Grand Island, NY, USA) supplemented with $0.35 \mathrm{~g} \mathrm{NaHCO}_{3} / 1,4.7 \mathrm{~g}$ Hepes/1; $1 \mathrm{~g} \mathrm{BSA} / 1 ; 0.079$ penicillin $\mathrm{G} / 1 ; 0.1 \mathrm{~g}$ streptomycin sulphate/l; and $0.05 \mathrm{~g}$ neomycin sulphate $/ 1, \mathrm{pH} 7 \cdot 35$, for transport to the laboratory. Corpora lutea were decapsulated, sliced and enzymically dissociated into single cell suspensions $(0.4 \%$ collagenase: Worthington Biochemical Corp., Malvern, PA, USA; 0.005\% DNAse; complete Hanks; pH 7.35; Hild-Petito et al., 1987). Dissociation proceeded by incubation of the slices in a shaking water bath at $37^{\circ} \mathrm{C}$ until visible clumps had disappeared, usually $3-5 \mathrm{~h}$. Dissociated cells were washed ( 5 times) and collected by centrifugation $\left(900 \mathrm{~g}, 4 \mathrm{~min}, 22^{\circ} \mathrm{C}\right.$ ) and resuspended in Medium 199. Single cell suspensions were separated into small and large cell fractions by elutriation as described by Fitz et al. (1982). Small cell fractions contained no large cells and were $95-99 \%$ viable as assessed by trypan blue dye exclusion. Large cell fractions contained 10-30\% small cell contamination (by number) and were $80-95 \%$ viable after elutriation.

Cell incubations. Suspensions of small $\left(5 \times 10^{4} / \mathrm{ml}\right)$ or large $\left(1 \times 10^{4} / \mathrm{ml}\right)$ luteal cells were incubated in $12 \times 75 \mathrm{~mm}$ glass disposable culture tubes containing $1 \mathrm{ml}$ complete Hanks' buffer $(0.1 \%$ BSA) under atmospheric conditions. Incubations contained Hanks' minus or plus calcium $(1.68 \mathrm{~mm})$ as indicated in the figure legends. Ionophore, TPA and sphingosine were suspended in DMSO, then added to media for cellular incubations. In all experiments utilizing these agents, control incubations were performed in the presence of an equal volume of DMSO. In some incubations, calcium-free medium was also supplemented with EGTA $(1.68 \mathrm{mM})$ to reduce further the effect of extracellular calcium that might be associated with the outer surface of the cells. Cellular suspensions were incubated in a New Brunswick metabolic shaker at $37^{\circ} \mathrm{C}$ for $2 \mathrm{~h}$ unless indicated otherwise. After the incubation period, media were collected after sedimentation of the cells by centrifugation $\left(900 \mathrm{~g}, 4 \mathrm{~min}, 22^{\circ} \mathrm{C}\right)$. The concentration of progesterone in the media was determined by radioimmunoassay as previously reported (Hild-Petito et al., 1987). Intra-assay and inter-assay coefficients of variation were $4.56 \%$ and $4 \cdot 24 \%$, respectively. Sensitivity was $3 \mathrm{pg}$. 
Cell viabilities. Cellular pellets were immediately resuspended in Medium 199 following collection of media at the end of cellular incubations. Viabilities were assessed by calculating percentages of small or large cells excluding trypan blue dye (Phillips, 1973).

Statistical analyses. Statistical differences were determinded by analysis of variance followed, when appropriate, by Newman-Keuls' multiple range testing. Comparisons between progesterone content of the media and cell viabilities were determined by correlation analysis. Differences in secretion of progesterone in cells incubated with or without $100 \mu \mathrm{M}$-sphingosine were determined by Student's $t$ test. Values for progesterone in the media were determined for each point in each experiment from the mean of triplicate incubation tubes. The number of separate experiments from which the data were calculated (expressed as mean of triplicate determinations) is indicated in each figure legend. Significance was assigned at the 0.05 level.

All chemicals were purchased from Sigma Chemical Company (St Louis, MO, USA) unless otherwise indicated. $\left[{ }^{3} \mathrm{H}\right]$ Progesterone was obtained from New England Nuclear Research Products (Boston, MA, USA). The antibody to progesterone was GDN-337, kindly provided by Dr G. D. Niswender. Ovine luteinizing hormone (NIAMDD-oLH24) was provided by the National Pituitary Agency (Bethesda, MD, USA).

\section{Results}

\section{Effect of ionophore}

To determine whether increases in intracellular calcium influence steroidogenesis in small or large cells, the effect of two concentrations of the calcium ionophore (A23187) on secretion of progesterone was measured (Table 1). These concentrations were in the ranges reported to stimulate calcium efflux $(1 \mu \mathrm{M})$ and promote cellular influx of calcium $(100 \mu \mathrm{M})$ in bovine epididymal spermatozoa (Babcock et al., 1976). Along with measurements of progesterone in the media, viability determinations were made by trypan blue dye exclusion following the 2-h incubation period for each treatment group. Incubation of small cells with ionophore did not affect secretion of progesterone or viability (which were not correlated). However, secretion of progesterone by small cells stimulated by luteinizing hormone ( $\mathrm{LH} ; 100 \mathrm{ng} / \mathrm{ml})$ or dbcAMP $(2 \mathrm{mM})$ was partly, but not completely, inhibited by A23187 (data not shown). This effect was similar to that seen with small cells stimulated with LH and incubated with the phorbol ester, TPA (see Fig. 5).

Table 1. Effect of increasing concentrations of ionophore (A23187) on progesterone in the media and cellular viabilities after incubation $\left(2 \mathrm{~h}, 37^{\circ} \mathrm{C}\right)$ with small and large luteal cells of sheep

\begin{tabular}{|c|c|c|c|c|}
\hline & \multicolumn{2}{|c|}{ Small cells } & \multicolumn{2}{|c|}{ Large cells } \\
\hline & $\begin{array}{c}\text { Progesterone } \\
\left(\mathrm{nmol} / 10^{6} \text { cells }\right)\end{array}$ & $\begin{array}{c}\text { Viability } \\
(\%)\end{array}$ & $\begin{array}{l}\text { Progesterone } \\
\left(\mathrm{nmol} / 10^{6} \text { cells }\right)\end{array}$ & $\begin{array}{c}\text { Viability } \\
(\%)\end{array}$ \\
\hline Control & $0 \cdot 158 \pm 0.050$ & $94 \cdot 4 \pm 2 \cdot 0$ & $1 \cdot 343 \pm 0 \cdot 186$ & $84 \cdot 2 \pm 2 \cdot 4$ \\
\hline $\begin{array}{c}\mathrm{A} 23187 \\
1 \mu \mathrm{M} \\
100 \mu \mathrm{M}\end{array}$ & $\begin{array}{l}0.146 \pm 0.060 \\
0.122 \pm 0.078\end{array}$ & $\begin{array}{l}89 \cdot 7 \pm 3 \cdot 6 \\
82 \cdot 5 \pm 3 \cdot 6\end{array}$ & $\begin{array}{l}0.913 \pm 0.146^{*} \\
0.646 \pm 0.040^{* *}\end{array}$ & $\begin{array}{l}72.8 \pm 3 \cdot 7 \\
39 \cdot 6 \pm 14 \cdot 2^{* *}\end{array}$ \\
\hline & \multicolumn{2}{|c|}{$r=0.28$} & \multicolumn{2}{|c|}{$r=0.68^{*}$} \\
\hline
\end{tabular}

Values represent mean \pm s.e. $(n=4$; triplicate determinations of 4 separate experiments). ${ }^{*} P<0.05,{ }^{* *} P<0.01$ compared with control; $r$ represents correlation coefficient for progesterone versus viability.

Secretion of progesterone by large cells significantly decreased in a dose-dependent manner upon incubation with ionophore, but cell viability was also selectively decreased. Secretion of progesterone and viability were significantly correlated in these cells. The time required for inhibition of secretion of progesterone by A23187 in large cells was significant $(P<0.05)$ by $2 \mathrm{~h}$ (Table 2). If the inhibition of secretion of progesterone in large cells by ionophore were due to increased intracellular calcium as it affects intracellular regulatory mechanisms, removal of calcium from the 
medium should prevent this effect. Figure 1 presents the results of an experiment measuring secretion of progesterone in small and large cells incubated for $2 \mathrm{~h}$ with A23187 in Hanks' medium plus or minus added calcium as well as EGTA. There was no effect of removal of extracellular calcium on secretion of progesterone or viability in small cells. Similar decreases in secretion of progesterone by large cells incubated with ionophore were observed whether calcium and/or EGTA were present in the media. These decreases in secretion of progesterone were significantly correlated $(P<0.05)$ with cell viabilities in large cells.

Table 2. Effect of time on progesterone in the media and cellular viabilities in sheep large luteal cells incubated $\left(37^{\circ} \mathrm{C}\right)$ with ionophore (A23187, $100 \mu \mathrm{M})$

\begin{tabular}{lcc}
\hline $\begin{array}{l}\text { Time } \\
\text { (h) }\end{array}$ & $\begin{array}{l}\text { Progesterone } \\
\text { (\% control) }\end{array}$ & $\begin{array}{c}\text { Viability } \\
\text { (\% control) }\end{array}$ \\
\hline 0.5 & $91.80 \pm 0.05$ & 100.0 \\
1.0 & $80.34 \pm 0.07$ & 85.29 \\
2.0 & $67.52 \pm 0.13^{*}$ & 61.47 \\
4.0 & $53.00 \pm 0.14^{*}$ & 71.49 \\
\hline
\end{tabular}

Control levels of progesterone were $1 \cdot 82(0.5 \mathrm{~h}), 2 \cdot 3(1 \mathrm{~h})$, $3.58(2 \mathrm{~h}), 4.60(4 \mathrm{~h}) \mathrm{nmol} / 10^{6}$ cells. Values for progesterone represent the mean \pm s.e. of 5 separate experiments $(n=5) ;{ }^{*} P<0.05$ compared with control. Viabilites are reported for one experiment.

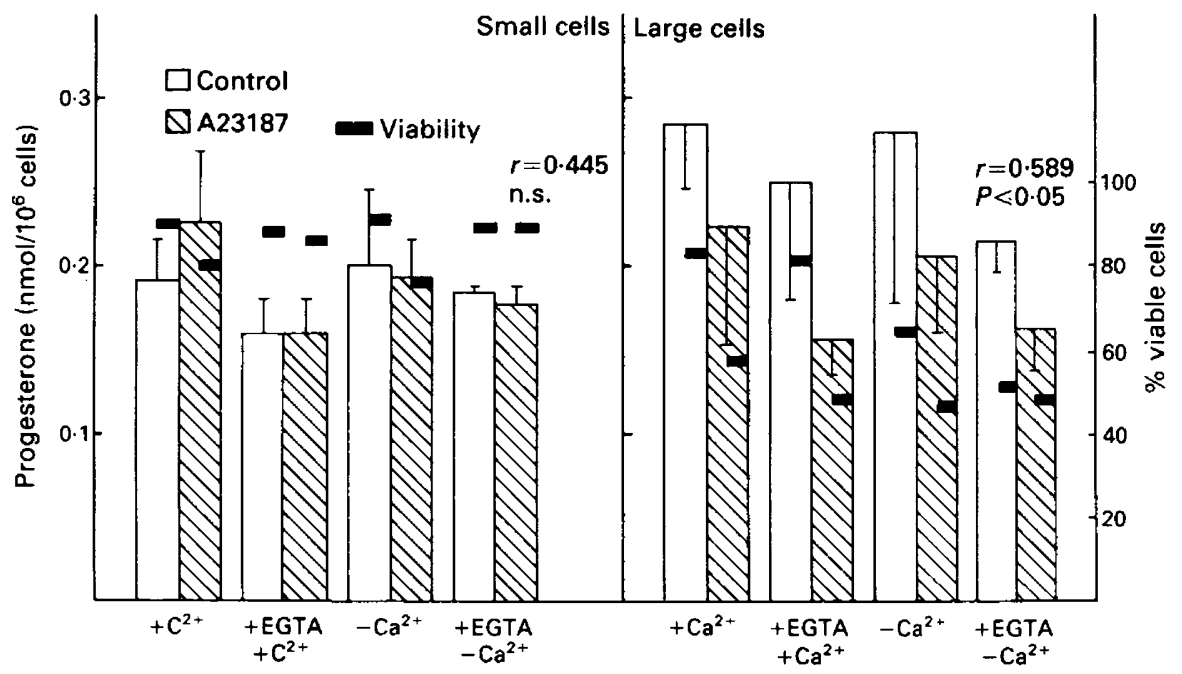

Fig. 1. Effect of ionophore on secretion of progesterone and cell viability in small or large cells incubated in media with or without added calcium $(1.68 \mathrm{~mm})$ and/or EGTA $(1.68 \mathrm{~mm})$. Values are mean \pm s.e. $(n=2)$ of 2 separate experiments each repeated in triplicate. Cellular viabilities after incubation are indicated by solid bands. Correlation coefficients $(r)$ for progesterone versus viabilities are indicated for both cell types. 


\section{Effect of phorbol ester}

Due to equivocal results obtained for incubation of large cells with ionophore, a probable involvement of protein kinase $\mathrm{C}$ in steroidogenesis in small and large cells was investigated. The tumour-promoting phorbol ester, phorbol 12-myristate, 13-acetate (TPA), has been widely used as an activator of protein kinase $\mathrm{C}$ in many tissues including bovine (Benhaim et al., 1987; Alila et al., 1988) and rat (Baum \& Rosberg, 1987) luteal cells. It was observed in initial experiments that low concentrations of TPA $(0 \cdot 1-100 \mathrm{nM})$ did not have an effect on secretion of progesterone in small or large cells (data not shown). Therefore, small and large cells were incubated with two higher concentrations of TPA (100 nM, $10 \mu \mathrm{M}$; Fig. 2). Secretion of progesterone and cell viabilities were determined after incubation for $2 \mathrm{~h}$. Secretion of progesterone and cell viabilities were not augmented $(P>0.05)$ in small cells incubated with TPA, but progesterone in the media of large cell incubations was decreased at $100 \mathrm{nM}(P<0.05)$ and $10 \mu \mathrm{M}(P<0.01)$ although cell viability was not affected. The correlation between progesterone in the media and cell viabilities was not significant $(P>0.05)$ in either cell type.

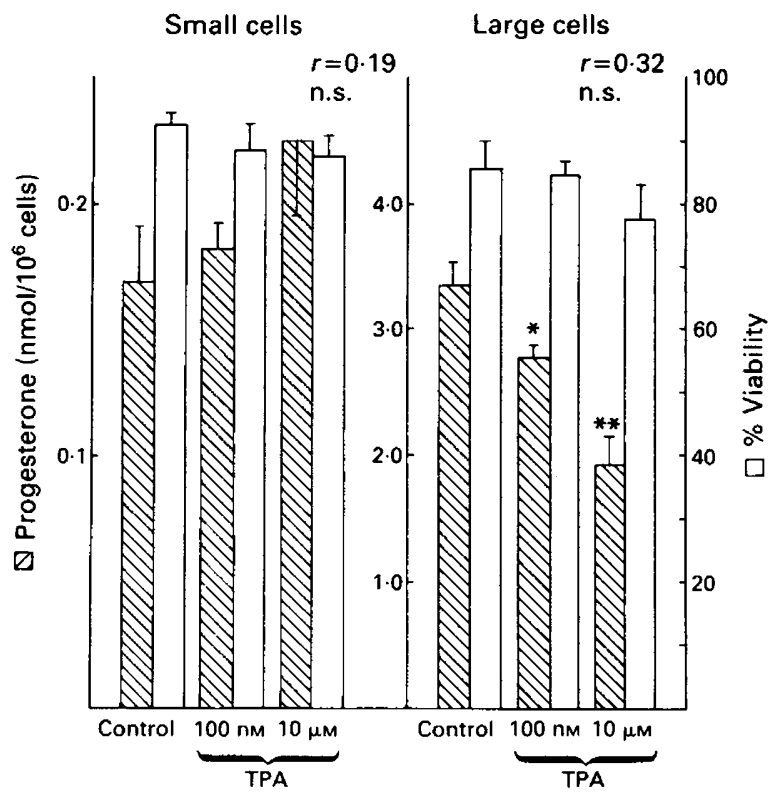

Fig. 2. Effect of TPA on secretion of progesterone and cellular viabilities in incubations of small and large cells. Values represent the mean \pm s.e. $(n=3)$ of 3 separate experiments each repeated in triplicate. ${ }^{*} P<0.05,{ }^{* *} P<0.01$ compared with control.

The specificity of response to TPA observed in large cells was tested by incubations of small and large cells with TPA as well as $4 \alpha$-phorbol-12,13 dideconate (4 $\alpha$-PDD), a non-tumour-promoting phorbol ester. Table 3 shows that, whereas secretion of progesterone by large cells was decreased by incubation with TPA, no effect of $4 \alpha-P D D$ was observed.

The requirement of extracellular calcium for the effect of TPA on large cells was determined (Fig. 3). Secretion of progesterone was decreased $(P<0.01)$ at both concentrations of TPA in large cells whether calcium was present or absent in the medium. Other experiments gave similar results for incubations of small and large cells with TPA in medium that was calcium-free and contained EGTA (data not shown). The apparent increase in secretion of progesterone in small cells by TPA was not significant in this or other experiments (Figs 2 \& 5). 
Table 3. Effect of increasing concentrations of phorbol 12myristate 13-acetate (TPA) and non-tumour-promoting $4 \alpha$ phorbol 12,13-didecanoate (4 $\alpha$-PDD) on media content of progesterone after incubation $\left(2 \mathrm{~h}, 37^{\circ} \mathrm{C}\right)$ with small and large luteal cells of sheep

\begin{tabular}{lccc}
\hline & & \multicolumn{2}{c}{ Progesterone $\left(\mathrm{nmol} / 10^{6}\right.$ cells) } \\
\cline { 3 - 4 } & & Small cells & Large cells \\
\hline Control & & $0 \cdot 144 \pm 0.012$ & $3.810 \pm 0.152$ \\
TPA & $100 \mathrm{nM}$ & $0.160 \pm 0.006$ & $2.977 \pm 0.022$ \\
& $10 \mu \mathrm{M}$ & $0.172 \pm 0.009$ & $1.627 \pm 0.007$ \\
$4 \alpha-P D D$ & $100 \mathrm{nM}$ & $0.144 \pm 0.010$ & $3.877 \pm 0.135$ \\
& $10 \mu \mathrm{M}$ & $0.141 \pm 0.006$ & $3.823 \pm 0.110$ \\
\hline
\end{tabular}

Values represent the mean \pm s.e. of triplicate determinations of a representative experiment.

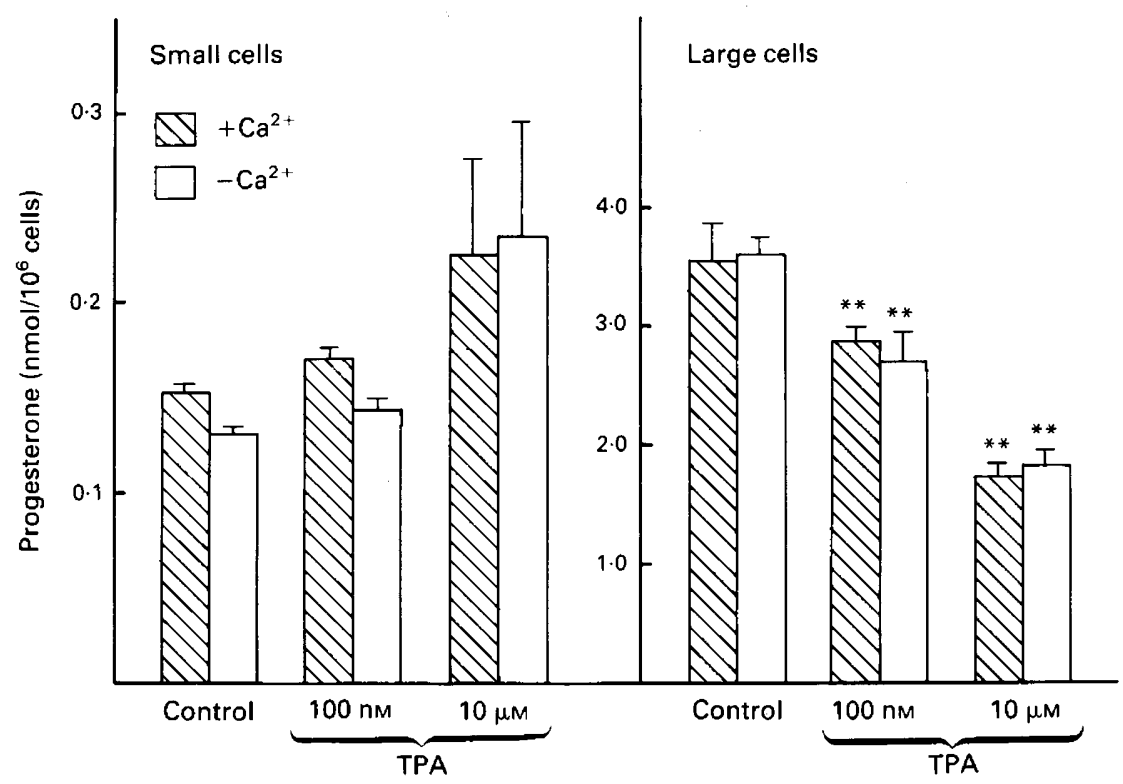

Fig. 3. Requirement of extracellular calcium for the effect of TPA on secretion of progesterone by small and large cells. Values represent the mean \pm s.e. $(n=2)$ of 2 separate experiments each repeated in triplicate. ${ }^{* *} P<0.01$ compared with control.

\section{Effect of sphingosine}

As an indicator of the specificity of effect of TPA on activation of protein kinase C in large cells, incubations were performed with increasing concentrations of sphingosine (Fig. 4) an agent shown to be inhibitory to $\mathrm{C}$ kinase activity in other systems. Media content of progesterone and cell viabilities were determined after the incubations. In small and large cells decreases in secretion of progesterone $(P<0.05)$ and viability $(P<0.01)$ were measured at $100 \mu \mathrm{M}$-sphingosine. These decreases were significantly correlated $(P<0.01)$ in both cell types. The addition of TPA $(10 \mu \mathrm{M}$; inhibitory in large cells to secretion of progesterone, but not viability) did not alter, at any concentration, the effect of sphingosine $(1-100 \mu \mathrm{M})$ on secretion of progesterone or viability in small or large cells (data not shown). 


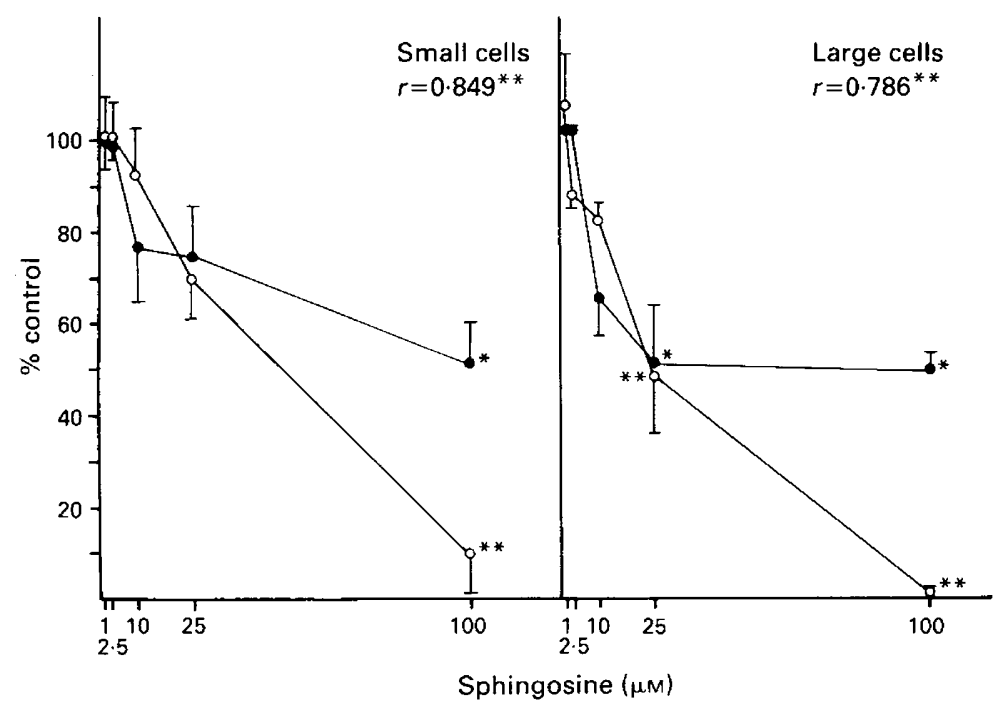

Fig. 4. Effect of increasing concentrations of sphingosine on secretion of progesterone and viability in small and large cells. Accumulation of progesterone (__ ) and cellular viabilities $(\mathrm{O}-\mathrm{O})$ ) were measured after incubation as described in 'Materials and Methods'. Values represent the mean $\%$ of control \pm s.e. $(n=3)$ of 3 separate experiments; progesterone values were each repeated in triplicate. ${ }^{*} P<0.05 ;{ }^{* *} P<0.01$ compared with control.

Since there was no augmentation by TPA in the secretion of progesterone in unstimulated small cells (Figs $2 \& 3$ ), the effect of TPA on hormone-stimulated secretion of progesterone in small cells was measured. Small cells were incubated with or without $\mathrm{LH}(100 \mathrm{ng} / \mathrm{ml})$ and $/$ or TPA $(10 \mu \mathrm{M})$. As expected, secretion of progesterone was stimulated $\left(P<0.01\right.$; control, $0.47 \pm 0.11 \mathrm{nmol} / 10^{6}$ cells $)$ 4.2 -fold by $\mathrm{LH}\left(1.93 \pm 0.04 \mathrm{nmol} / 10^{6}\right.$ cells $)$. No effect of TPA alone was measured $(P>0.05$; $0.57 \pm 0.24 \mathrm{nmol} / 10^{6}$ cells); secretion of progesterone was above basal $(2.6$-fold; $P<0.05$; $1 \cdot 21 \pm 0.12 \mathrm{nmol} / 10^{6}$ cells $)$, but below hormone-stimulated $(P<0.05)$ levels in LH/TPA-treated cells.

\section{Discussion}

The current study was undertaken to determine whether calcium serves as an intracellular regulator of progesterone secretion in ovine small and/or large luteal cells. Initial experiments utilized the calcium ionophore, A23187, to provide generalized increases in intracellular calcium. This ionophore has been widely used for this purpose in many cell types. Babcock et al. (1976) described the effect of A23187 on plasma and mitochondrial membrane transport of calcium in bovine epididymal spermatozoa: at lower concentrations $\left(10^{-6} \mathrm{M}\right)$, A23187 stimulated calcium efflux, while at slightly higher concentrations $\left(10^{-5}\right.$ to $\left.10^{-4} \mathrm{M}\right)$ it promoted calcium influx into a nonmitochondrial compartment of the sperm cell. An inhibitory effect of A23187 on steroidogenesis was previously reported. Incubation of rat adrenocortical cells with A23187 (1-40 $\mu \mathrm{M})$ resulted in inhibition of steroidogenesis stimulated by ACTH or cAMP (Farese et al., 1981). LH-stimulated secretion of progesterone in pig granulosa cells was increased by low concentrations of A23187 $(0.2 \mu \mathrm{M})$ but inhibited at higher concentrations $(20 \mu \mathrm{M}$; Veldhuis \& Klase, 1982). However, the higher concentration of ionophore reduced rather than enhanced intracellular calcium levels. In the present study, incubation of small cells did not have an effect on secretion of progesterone. Conversely, secretion of progesterone by large cells was inhibited. Further evaluation of this effect, however, revealed that viability, as determined by trypan blue dye exclusion, was decreased in large 
but not small cells by these incubations and this decrease in cell viability was significantly correlated with secretion of progesterone. These observations suggest that calcium acting as an intracellular mediator may not have been responsible for the inhibition of progesterone production in large cells.

A reduction in extracellular calcium did not reverse the inhibition of steroid production by A23187 in large cells and cellular viability was still correlated with secretion of progesterone. Intracellular calcium levels were not directly measured in these experiments. However, these results provide evidence that the effect of ionophore on large cells is not due to increased intracellular levels of calcium. Furthermore, it cannot be ruled out that, in response to A23187, even in calcium-free medium supplemented with EGTA, intracellular calcium levels have become elevated as a result of efflux into the cytosolic compartment from intracellular sites of calcium storage. Experiments are currently in progress to correlate directly changes in intracellular calcium with secretion of progesterone in small and large cells.

Since the results obtained with ionophore were not readily interpretable, incubations of small and large cells were performed in media containing the phorbol ester, TPA. Phorbol esters have been widely used in cellular incubations to activate intracellular events stimulated by protein kinase $\mathrm{C}$, which has been shown to be the cellular receptor for binding of phorbol esters (Kikkawa et al., 1983). Three or 4 isoenzymic forms of $\mathrm{C}$ kinase have been identified in rat brain tissue in studies utilizing polyclonal antibodies (Huang et al., 1986), mRNA probes (Coussens et al., 1986) and enzyme purification by h.p.l.c. (Pelosin et al., 1987). In the latter study, the isoenzymes differed in their responsiveness to activation by TPA. Differences in response to incubation with TPA between small and large cells in this study may be due to differences in their isoenzyme content. However, bovine adrenocortical tissue contained only one isoenzyme form (Pelosin et al., 1987). Further experiments are required to examine this possibility. Variable effects of incubation of phorbol esters with steroidogenic tissues have been reported (Brunswig et al., 1986; Hansel \& Dowd, 1986; Baum \& Rosberg, 1987; Benhaim et al., 1987; Wiltbank et al., 1988; Alila et al., 1988; Hoyer et al., 1988).

Lower concentrations of TPA were ineffective in either cell type. Unstimulated small cells incubated with TPA at $100 \mathrm{nM}$ and $10 \mu \mathrm{M}$ did not respond with significantly augmented secretion of progesterone or cell viability. However, secretion of progesterone in small cells stimulated with $\mathrm{LH}$ was partly decreased by TPA, but not lowered to basal values. Similar results were obtained for incubations of small cells stimulated with dbcAMP (data not shown). These observations are similar to those reported by Baum \& Rosberg (1987) for rat luteal cells. This suggests that protein kinase $C$ in small cells may serve to prevent maximal stimulation of steroidogensis by LH. This may relate to the mechanism by which luteolysis is induced in these cells. Protein kinase $\mathrm{C}$ activity was directly measured in small cells and proteins that can serve as endogenous substrates for C kinase were observed in soluble fractions of these cells (Hoyer et al., 1988; Hoyer \& Kong, 1989).

Large cells incubated with TPA responded with an inhibition of secretion of progesterone. This observation was not accompanied by decreased viabilities of large cells following incubation. Therefore, inhibition of progesterone production as a result of intracellular regulatory events in these cells seems likely. Specificity of the observed effect was suggested in incubations which compared the effect of TPA with that of $4 \alpha-P D D$, a non-tumour promoting phorbol ester. In these incubations, secretion of progesterone was not different between control and $4 \alpha-P D D$-treated cells.

Incubations of cells with TPA in calcium-free medium demonstrated that extracellular calcium is not required for the effect of TPA on large cells. This finding is to be expected if the effect is due to activation of protein kinase $\mathrm{C}$ since activation of the enzyme by phorbol esters by-passes the requirement for increased intracellular calcium levels (Nishizuka, 1984).

Direct measurement of protein kinase $\mathrm{C}$ activity in large cells indicated that a lower $(P<0.05)$ level of phosphotransferase activity is present in these cells compared with that in small cells (Hoyer et al., 1988; Hoyer \& Kong, 1989). However, endogenous proteins in large cells served as endogenous substrates for phosphorylation by $\mathrm{C}$ kinase in these studies. Therefore, $\mathrm{C}$ kinase activity may be present in low levels in these cells, but that small amount of activity may play a physiologically significant role. 
Sphingosine has been demonstrated to be inhibitory to phosphorylation of the protein of $M_{\mathrm{r}} 40000$ known to be a substrate for protein kinase $\mathrm{C}$ in platelets (Hannun et al., 1986) and the $M_{\mathrm{r}} 80000$ protein known to be a substrate for C kinase in BALB/C 3T3 cells (Gillies et al., 1989). Incubation of platelets with sphingosine has been shown to inhibit agonist-dependent secretion and activation that is attributed to $C$ kinase-mediated cellular mechanisms (Hunnun et al., 1987). Sphingosine has been further utilized to inhibit protein kinase C-induced differentiation of human promyelocytes as well as neutrophil activation (Merrill et al., 1986; Wilson et al., 1986). Phosphorylation of endogenous proteins in the soluble fractions of small and large sheep luteal cells which was stimulated by TPA was completely inhibited by the addition of $200 \mu \mathrm{M}$-sphingosine (Hoyer \& Kong, 1989). Therefore, sphingosine inhibits in-vitro phosphorylation of endogenous proteins as stimulated by activation of endogenous protein kinase $\mathrm{C}$ in small and large cells (Hoyer et al., 1988; Hoyer \& Kong, 1989).

If sphingosine were acting as a specific inhibitor of protein kinase $\mathrm{C}$ in small and/or large cells, secretion of progesterone in these incubations should be unaltered in unstimulated small cells and increased in large. The effect of sphingosine on secretion of progesterone by both cell types, however, was inhibitory. This effect occurred in a dose-dependent manner. Further investigation of this phenomenon revealed that cell viability was decreased in both cell types after incubation. Secretion of progesterone and viability were significantly correlated in small as well as in large cells. The presence of TPA was unable to prevent this effect in either cell type. Therefore, lower concentrations of sphingosine $(1-25 \mu \mathrm{M})$, did not reverse inhibition of progesterone secretion by TPA in large cells. No conclusions about the ability of sphingosine to reverse the effects of $\mathrm{C}$ kinase on steroidogenesis in these cells can be made from these incubations. This same effect of $100 \mu \mathrm{M}-$ sphingosine on cellular viability (small and large cells) was observed within 5 min incubation (data not shown).

In summary, these experiments have demonstrated the following points. Ionophore (A23187) has a selective effect on large luteal cells. The nature of this effect may be non-specific since decreases in secretion of progesterone and cell viability were still observed in incubations with reduced extracellular calcium. However, this effect may also be of physiological significance since luteal regression is thought to be mediated by large cells (Fitz et al., 1982, 1984) and luteolysis involves cellular and tissue death. Sphingosine could not be demonstrated as a specific inhibitor of protein kinase $\mathrm{C}$ activity since cell viability was markedly reduced $(P<0.01)$ in both cell types in these incubations. Finally, protein kinase $C$ appears to regulate steroidogenesis negatively in unstimulated large and LH-stimulated small cells. This regulation may be involved in luteal regression induced by PGF-2 $\alpha$ as suggested by Baum \& Rosberg (1987). Further experiments are under way to examine this possibility as well as the mechanisms by which this regulation occurs.

This work was supported by NIH grant HD 20613 and a Flinn Foundation Award. We thank Ms Julie Wegner for assistance with statistical analyses; Mr Walt Englenberg for technical assistance; and Ms Dorothy Perkins for manuscript preparation.

\section{References}

Alila, H.W., Dowd, J.P., Corradino, R.A., Harris, W.V \& Hansel, W. (1988) Control of progesterone production in small and large bovine luteal cells separated by flow cytometry. $J$. Reprod. Fert. 82, 645-655.

Babcock, D.F., First, N.L. \& Lardy H.A. (1976) Action of ionophore A23187 at the cellular level. Separation of effects at the plasma and mitochondrial membranes. J. biol. Chem. 251, 3881-3886.

BaLapure, A.K., Watt, D.S., Rexroad, C.E., Jr \& Fitz, T.A. (1988) $\mathrm{PGF}_{2} \alpha$ receptors in ovine luteal cells (OLC). Biol. Reprod. (Suppl. 1), 38, Abstr. 396.
Baum, M.S. \& Rosberg, S. (1987) A phorbol ester, phorbol 12-myristate 13-acetate, and a calcium ionophore, A23187, can mimic the luteolytic effect of prostaglandin $F_{2} \alpha$ in isolated rat luteal cells. Endocrinology 120, 1019-1026.

Benhaim, A., Herrou, M., Mittre, H. \& Leymarie, P. (1987) Effects of phorbol esters on steroidogenesis in small bovine luteal cells. FEBS Lett. 223, 321-326

Berridge, M.J. (1984) Inositol triphosphate and diacylgycerol as second messengers. Biochem. J. 220, 345-360. 
Brunswig, B., Mukhopadhyay, A.D., Budnik, L.T., Bohnet, H.G. \& Leidenberger, F.A. (1986) Phorbol ester stimulates progesterone production by isolated bovine luteal cells. Endocrinology 118, 743-749.

Clark, M.R., Davis, J.S. \& Lemaire, W.J. (1983) Calciumand lipid-dependent protein phosphorylation in the human ovary. J. clin. Endocr. Metab. 57, 872-874.

Coussens, L., Parker, P.J., Rhee, L., Yang-Feng, T.L., Chen, E., Waterfield, M.D., Francke, U. \& Ullrich, A. (1986) Muliple, distinct forms of bovine and human protein kinase $\mathrm{C}$ suggest diversity in cellular signaling pathways. Science, N.Y. 233, 859-866.

Davis, J.S. \& Clark, M.R. (1983) Activation of protein kinase in the bovine corpus luteum by phospholipid and $\mathrm{Ca}^{2+}$. Biochem. J. 214, 569-574.

Davis, J.S., Weakland, L.L., Farese, R.V. \& West, L.A. (1987a) Luteinizing hormone increases inositol trisphosphate and cytosolic free $\mathrm{Ca}^{2+}$ in isolated bovine luteal cells. J. biol. Chem. 262, 8515-8521.

Davis, J.S., Weakland, L.L. Weiland, D.A. Farese, R.V. \& West, L.A. (1987b) Prostaglandin $F_{2} \alpha$ stimulates phosphatidylinositol 4,5-bisphosphate hydrolysis and mobilized intracellular $\mathrm{Ca}^{2+}$ in bovine luteal cells. Proc. natn. Acad. Sci. USA 84, 3728-3732.

Farese, R.V., Sabir, M.A. \& Larson, R.E. (1981) A23187 inhibits adrenal protein synthesis and the effects of adrenocorticotropin (ACTH) on steroidogenesis and phospholipid metabolism in rat adrenal cells in vitro: further evidence implicating phospholipids in the steroidogenic action of ACTH. Endocrinology 108, 1243-1246.

Fitz, T.A., Mayan, M.H., Sawyer, H.R. \& Niswender, G.D. (1982) Characterization of two steroidogenic cell types in the ovine corpus luteum. Biol. Reprod. 27, 703-711.

Fitz, T.A., Mock, E.J., Mayan, M.H. \& Niswender, G.D. (1984) Interactions of prostaglandins with subpopulations of ovine luteal cells. II. Inhibitory effects of $\mathrm{PGF}_{2} \alpha$ and protection by $\mathrm{PGE}_{2}$. Prostaglandins 28, 127-135.

Gillies, R.J., Martinez, R., Sneider, J.M., \& Hoyer, P.B. (1989) Sphingosine inhibits phorbol ester but not serum-induced activation of $\mathrm{Na}^{+} / \mathrm{H}^{+}$exchange in BALB/C 3T3 cells. J. cell. Physiol. (in press).

Hannun, Y.A., Carson, R.L., Merrill, A.H., Jr \& Bell, R.M. (1986) Sphingosine inhibition of protein kinase $\mathrm{C}$ activity and of phorbol dibutyrate binding in vitro and in human platelets. J. biol. Chem. 261, $12604-12609$.

Hannun, Y.A., Greenberg, C.S. \& Bell, R.M. (1987) Sphingosine inhibition of agonist-dependent secretion and activation of human platelets implies that protein kinase $\mathrm{C}$ is a necessary and common event of the signal transduction pathways. $J$. biol. Chem. 262, 13630-13626.

Hansel, W. \& Dowd, J.P. (1986) New concepts of the control of corpus luteum function. J. Reprod. Fert. 78, 755-768.

Hild-Petito, S., Ottobre, A.C. \& Hoyer, P.B. (1987) Comparison of subpopulations of luteal cells obtained from cyclic and superovulated ewes. $J$. Reprod. Fert. 80, 537-544.

Hoyer, P.B. \& Kong, W. (1989) Protein kinase A and C activities and endogenous substrates in ovine small and large luteal cells. Molec. Cell. Endocr. (in press).
Hoyer, P.B. \& Niswender, G.D. (1985) The regulation of steroidogenesis is different in the two types of ovine luteal cells. Can. J. Physiol. Pharm. 63, 240-248.

Hoyer, P.B. \& Niswender, G.D. (1986) Adenosine 3',5'monophosphate-binding capacity in small and large ovine luteal cells. Endocrinology 119, 1822-1829.

Hoyer, P.B., Fitz, T.A. \& Niswender, G.D. (1984) Hormone-independent activation of adenylate cyclase in large steroidogenic ovine luteal cells does not result in increased progesterone secretion. Endocrinology 114, $604-608$.

Hoyer, P.B., Kong, W. \& Marion, S.L. (1988) Investigation of the role of $\mathrm{Ca}^{2+}$ phospholipid-dependent protein kinase in small and large ovine luteal cells. Biol. Reprod. (Suppl. 1) 38, Abstr. 20.

Huang, K., Nakabayashi, H. \& Huang, F.L. (1986) Isozymic forms of rat brain $\mathrm{Ca}^{2+}$-activated and phospholipid-dependent protein kinase Proc. natn. Acad. Sci. USA 83, 8535-8539.

Kikkawa, U., Takai, Y., Tanaka, Y., Miyake, R. \& Nishizuka, Y. (1983) Protein kinase C as a possible receptor protein of tumor-promoting phorbol esters. $J$. biol. Chem. 258, 11442-11445.

Maizels, E.T. \& Jungmann, R.A. (1983) $\mathrm{Ca}^{2+}$-calmodulindependent phosphorylation of soluble and nuclear proteins in the rat ovary. Endocrinology 112, 1895-1902.

Marsh, J.M. (1970) The stimulaory effect of luteinizing hormone on adenyl cyclase in the bovine corpus luteum J. biol. Chem. 245, 1596-1603.

Marsh, J.M., Butcher, R.W., Savard, K. \& Sutherland, E.W. (1966) The stimulatory effect of luteinizing hormone of adenosine $3^{\prime}, 5^{\prime}$-monophosphate accumulation in corpus luteum slices. J. biol. Chem. 241, 5436-5440.

McCracken, J.A., Glew, M.E. \& Scaramuzzi, R.J. (1970) Corpus luteum regression induced by prostaglandins $\mathrm{F}_{2} \alpha$. J. clin. Endocr. Metab. 30, 544-546.

Merrill, A.H., Jr, Sereni, A.M., Stevens, V.L., Hannun, Y.A., Bell, R.M. \& Kinkade, J.M., Jr (1986) Inhibition of phorbol ester-dependent differentiation of human promyelocytic leukemic (HL-60) cells by sphingosine and other long chained bases. J. biol. Chem. 216, 12610-12615.

Nishizuka, Y. (1984) Turnover of inositol phospholipids and signal transduction. Science, N.Y. 225, 1365-1367.

O'Shea, J.D., Cran, D.G. \& Hay, M.F. (1979) The small luteal cell of the sheep. J. Anat. 128, 239-251.

Pelosin, J., Vilgrain, I. \& Chamboz, E.M. (1987) A single form of protein kinase $\mathrm{C}$ is expressed in bovine adrenocortical tissue, as compared to four chromatographically resolved isozymes in rat brain. Biochem. Biophys. Res. Commun. 147, 382-391.

Phillips, H.F. (1973) Dye exclusion tests for cell viability. In Tissue Culture: Methods and Applications, pp. 406-408. Eds J. Kruse \& J. Patterson. Academic Press, London.

Rao, M.C., Palfrey, H.C., Nash, N.T., Greisman, A., Jayatilak, P.G. \& Gibori, G. (1987) Effects of estradiol on calcium-specific protein phosphorylation in the rat corpus luteum. Endocrinology 120, 1010-1018.

Rodgers, R.J. \& O'Shea, J.D. (1982) Purification, morphology and progesterone production and content of 
three cell types isolated from the corpus luteum of the sheep. Aust. J. biol. Sci. 35, 441-445.

Rodgers, R.J., O'Shea, J.D. \& Findlay, J.D. (1983) Progesterone production in vitro by small and large ovine luteal cells. J. Reprod. Fert. 69, 113-124.

Veldhuis, J.D. \& Klase, P.A. (1982) Role of calcium ions in the stimulatory actions of luteinizing hormone in isolated ovarian cells: studies with divalent cation ionophores. Biochem. Biophys. Res. Commun. 104, 603-610.

Wheeler, M.B. \& Veldhuis, J.D. (1987) Catalytic and receptor-binding properties of the calcium-sensitive phospholipid-dependent protein kinase (protein kinase C) in swine luteal cytosol. Molec, cell. Endocr. 50, 123-129.

Wilson, E., Olcott, M.C., Bell, R.M., Merrill, A.H., Jr \& Lambeth, J.D. (1986) Inhibition of the oxidative burst in human neutrophils by sphingoid long-chain bases. J. biol. Chem. 261, 12 616-12623.

Wiltbank, M.C., Knickerbocker, J.J., Kenny, N. \& Niswender, G.D. (1988) Modulation of luteal progesterone $\left(\mathrm{P}_{4}\right)$ production by protein kinase $\mathrm{C}$. Biol. Reprod. (Suppl. 1), 38, Abstr. 154.

Received 9 August 1988 